\author{
Nika CIGOJ \\ Davorin GAZVODA
}

\title{
Spreminjanje podobe naselij enodružinskih hiš: primerjalna analiza naselij v Ljubljani, Mariboru in Novem mestu
}

\begin{abstract}
Oblikovanje, zastopanost, velikost in organizacija odprtih površin v stanovanjskih naseljih enodružinskih hiš se v zadnjih štiridesetih letih močno spreminjajo. Da bi ugotovili trende in spremembe $v$ gradnji enodružinskih naselij, je bila izvedena primerjalna analiza izbranih naselij enodružinskih hiš v Ljubljani, Mariboru in Novem mestu. Ugotovljeno je bilo močno zmanjševanje površin odprtega prostora naselij in opuščanje zelenih površin. Pomanjkanje prostora in večanje izkoristka posameznih parcel z zgoščevanjem pozidave onemogočata vnos zelenih površin v ulični prostor in prostor predvrtov ter ustvarjanje skupnih površin naselij, namenjenih druženju, igri in rekreaciji prebivalcev. Posledici zmanjševanja bivalnih vrtov in višanja objektov sta neustrezna podoba novejših naselij enodružinskih hiš in siromašenje kakovosti bivanja zaradi zmanjševanja obsega zelenih površin. Uporaba odprtega prostora je odvisna od družbenih razmer posameznega obdobja, a vseeno ostajajo parametri, ki določajo kakovostno bivalno okolje, nespremenjeni. Zato bi bilo treba v prihodnje posvetiti več pozornosti problematiki načrtovanja stanovanjskih naselij z zagotavljanjem odprtega prostora in poiskati ustrezno razmerje med tržno logiko urbanizacije in predpisanimi urbanističnimi normativi.
\end{abstract}

KLJUČNE BESEDE: naselja enodružinskih hiš, organizacija in oblikovanje odprtega prostora, ulični prostor, podoba naselij, prostorska podoba.

\section{Uvod}

Urbanizacija kakovostnih slovenskih kulturnih krajin, zlasti pozidava Krasa, sproža različne polemike tako v laični kot v strokovni javnosti. Zazidalni načrti, ki smo jim priča v zadnjem času, prikazujejo nove zazidalne vzorce, ki so v marsičem nezdružljivi z obstoječimi grajenimi vzorci, še zlasti kadar gre za pozidavo primestnega oz. vaškega prostora. Pri tem ne gre samo za problem ohranjanja kakovostnih vaških jeder in ustreznega oživljanja podeželja, ampak,
The design, representation, size, and organization of open spaces in residential areas of single-family houses has undergone significant change in the last forty years. In order to identify trends and changes in the construction of settlements of single-family houses, a comparative analysis of selected settlements in Ljubljana, Maribor, and Novo mesto was performed. It was determined that there has been a sharp reduction in open spaces, including planted and green areas, in these kinds of settlements. The shortage of land and the increased use of parcels with high density building projects have discouraged the development of planted areas along streets and the creation of gardens and common areas intended for socializing, playing, and recreation. The reduction of residential gardens and the increased elevation of buildings often results in the unsuitable physical appearance of new settlements as well as in the impoverished quality of life, an inevitable consequence of scarce greenery and common areas. Despite the fact that the use of open space is dependant on social conditions during various time periods, certain parameters that determine the quality of living space remain constant. Because of this, it has become increasingly urgent to dedicate thought to the planning of residential areas that gives a larger proportion of their area to open spaces and seeks a more appropriate balance between the market logic of urbanization and certain proscribed urban standards.

KEY WORDs: single-family house settlements, organization and design of open space, street space, settlement appearance, over-all spatial appearance.

Žal, v prvi vrsti za neustrezne osnovne gabarite in merila nove pozidave kot take, ne glede na prostorski kontekst, v katerem se gradnja predvideva. Z nekakovostno pozidavo se ne spreminjata samo struktura in podoba mest, primestij in podeželja, ampak celotnega slovenskega prostora. Sprejemljivo število prostorskih enot, tako parcel kot različnih objektov, njihova gostota, temeljni urbanistični standardi organizacije in oblikovanja osnovne prometne infrastrukture so osnovni pojmi, ki jih bo treba čim prej jasno dopolniti in sprejeti nedvoumna pravila 
za gradnjo ne samo $\mathrm{z}$ omejevanjem investitorjev, ampak zlasti $\mathrm{z}$ zagotavljanjem razvoja, vendar $\mathrm{s}$ kakovostnim urbanizmom in arhitekturo ter oblikovanjem odprtega prostora naselij, ki zaokrožuje njihovo podobo. Pri reševanju tega problema je lahko dobrodošla že podrobnejša primerjava podobe naselij enodružinskih hiš v Sloveniji vsaj v zadnjih štiridesetih letih, da bi ugotovili, koliko so se spreminjali osnovni gabariti in organizacija teh naselij $\mathrm{v}$ izbranih mestih in naseljih.

Med enodružinskimi hišami v Sloveniji še vedno prevladuje prostostoječa hiša. Načrtovane gradnje enodružinskih hiš je malo oziroma je zgrajenih enot premalo za oblikovanje večjih zaključenih naselij, ki bi s svojo kompleksno organizacijo in prometno ter komunalno infrastrukturo ter odprtim prostorom ustvarjala zaokrožena manjša mesta. Velikost območja, namenjenega novogradnji, vpliva na podobo in razmeščanje bivalnih enot naselja ter s tem na podobo širšega prostora, v katerem se gradi. Dodajanje novih majhnih grajenih vzorcev ob tradicionalna naselja, zlasti na podeželju, je že v izhodišču lahko problematično. Manjše ko je območje, težje je zagotavljanje kompleksnega sistema formacij, ki bi dobivale svoj lastni značaj, bodisi $v$ organizaciji naselja $\mathrm{v}$ širšem smislu bodisi v arhitekturnem in krajinskem oblikovanju. Več manjših stanovanjskih nizov, načrtovanih ločeno drug od drugega, teže zagotavlja povezanost celote. Načrtovanje in oblikovanje posameznih enot mesta vplivata na njegovo celostno podobo, pri čemer ni samo arhitektura tista, ki oblikuje mestni prostor. Kakšna bosta videz in kakovost bivanja v mestu, je odvisno tudi od zastopanosti, namembnosti in oblikovanja odprtega prostora ob grajenem tkivu. Zlasti v stanovanjskih naseljih je za kakovost bivanja zelo pomembno vključevanje zelenih površin v urejanje območij zaradi njihovega prostorskooblikovalskega, socialnopsihološkega in ekološkega vidika.

Če so pred desetletji gradili naselja večjih razsežnosti, je bil tudi delež odprtih površin večji. Večji so bili odmiki med posameznimi enotami, racionalnejše so bile zasnove infrastrukturnih omrežij. Celostna zasnova je tako omogočala večjo individualnost posameznih bivalnih enot, obenem pa ponujala kakovostno zasnovan grajeni prostor.

\section{Pregled razvoja gradnje enodružinskih hiš v Sloveniji v obdobju od 1950 do 2000}

Po letu 1950 se je v Sloveniji začela pojavljati organizirana oziroma načrtovana enodružinska gradnja.
Zagotavljala je kakovostnejši prostor in stanovanjsko okolje s členitvijo odprtih površin, prometnih povezav, interakcij med objektom in vrtom ter med posameznimi enotami v naseljih. Načrtovana oziroma nadzorovana gradnja naj bi zaustavila pretežno stihijsko nastajanje enodružinskih prostostoječih hiš in povečevala bivanjsko kakovost teh naselij. Tako bi zagotovili racionalnejšo izrabo zemljišč, bolj usklajeno arhitekturno in urbanistično podobo naselja kot celote, zadovoljili bi družbena pričakovanja in prizadevanja stroke.

Primanjkljaj stanovanj $\mathrm{v}$ povojnem obdobju so v petdesetih letih reševali $z$ gradnjo večstanovanjskih blokovnih sosesk, zato je med tipologijo enodružinske gradnje vladalo stihijsko in nenačrtno graditeljstvo posameznikov. Po letu 1950 je bila sprejeta nova zakonodaja, ki je razbremenila državno centralizacijo upravljanja v delavsko samoupravljanje. Hkrati si je stroka prizadevala za izboljšanje razmer. Nastale so prve sodobne enodružinske hiše v Sloveniji, ki so bile nove po prostorskih in tehnoloških inovacijah (Koselj, 2005). Družbena in gospodarska reforma leta 1965 je stanovanje iz socialne dobrine prekvalificirala $\mathrm{v}$ tržno blago, kar je povzročilo izjemno povečanje gradnje enodružinskih hiš (Ivanšek, 1998). Samograditeljska praksa ali celo stihijska gradnja s pojavi črnih gradenj ni izkazovala regijskih značilnosti. Pojavljala se je nenačrtovano, velikokrat tudi na območjih, ki za gradnjo niso bila predvidena, kar je privedlo do družbeno, prostorsko in ekonomsko potratne pozidave zlasti na obrobju mest, kjer so bila »zemljišča v prostem prometu, stanovanjskih kreditov ni bilo, in si je tako nedovoljena gradnja počasi pridobivala 'državljansko pravico'« (Bojovič, 1984: 5).

V Studiu za stanovanje in opremo (samostojni zavod, ki ga je 1. 1963 ustanovil France Ivanšek) so oblikovali posebno strokovno skupino za enodružinsko gradnjo, ki bi opravljala raziskovalno, dokumentacijsko, projektantsko in svetovalno delo za izboljšanje kakovosti enodružinske gradnje (Ivanšek, 1998).

Razmere v gradnji enodružinskih hiš so se začele izboljševati v začetku 70. let, ko se je začela uveljavljati organizirana strnjena gradnja enodružinskih, večinoma vrstnih hiš, ki je, v primerjavi s stanovanjem v bloku, omogočala možnost individualnega razvoja družine v lastni hiši. S popularizacijo problema kakovosti stanovanjskega okolja je del prebivalstva začel izkazovati željo po bivanju v območjih z večjim vnosom naravnih prvin.

Konec 80. let se je stanovanjska gradnja z zaostrovanjem gospodarskih razmer močno upočasnila. Sprejetje nove stanovanjske zakonodaje, ki naj bi uredila 
projektantsko dejavnost, spremembe $\mathrm{v}$ lastništvu zemljišč in priprava Nacionalnega stanovanjskega programa v začetku 90. let so se odprle možnosti za celovitejše lotevanje spreminjanja razmer pri stanovanjski gradnji. Žal pa številni kakovostni zazidalni načrti v novonastali tranzicijski družbi niso več ustrezali liberalnim tržnim razmeram, zato so se, vsaj z vidika kakovosti teh naselij, začeli "popravljati« na slabše. Vzporedno je začelo primanjkovati zemljišč za gradnjo. Nesorazmerje med povpraševanjem in ponudbo se je čedalje bolj povečevalo. Z diferenciacijo družbe se je spremenil odnos do tedaj usmerjene gradnje.

Stanje v sredini 90. let je bilo podobno stanju pred družbenim in strokovnim prizadevanjem za kakovostno bivalno okolje $\mathrm{v}$ 60. letih. Najpogostejši tip enodružinske zazidave je bila še vedno gradnja samostojno stoječe hiše. Samograditeljstva je bilo manj zaradi spremenjenih gospodarskih razmer, vendar je bil tudi položaj pri organizirani enodružinski gradnji neurejen. Pojavljali so se isti problemi, kakršne je opisovala že literatura iz preteklosti (Krušec in Žaucer, 1996).

Kljub visokim cenam stavbnih zemljišč in drugim težavam pri gradnji ostaja enostanovanjska hiša bivalni ideal večine Slovencev. Raziskava Kakovost stanovanjske oskrbe in bivalnega okolja Urbanističnega inštituta iz leta 2002 je analizirala javnomnenjske raziskave med letoma 1969 in 1994, ki jih je opravil Center za raziskovanje javnega mnenja in množičnih komunikacij (Šašek-Divjak in dr., 2002). Izsledki analize kažejo, da je več kot polovica vprašanih ljudi (68,9 odstotka) že stanovala v lastni hiši. Tistih, ki so živeli v različnih tipih večstanovanjskih hiš in bi v enostanovanjski želeli stanovati, je bilo kar 93,4 odstotka (zadnja raziskava javnega mnenja iz leta 1986). Stanovanjska anketa, zajeta v Razvojno-raziskovalnem projektu Fakultete za družbene vede Univerze v Ljubljani (Mandič in sod., 2006), ki so jo izdelali za raziskavo stanja in trendov stanovanjske oskrbe gospodinjstev v Sloveniji, ponuja nekatere podatke, ki so zanimivi tudi zaradi načrtovanja naselij. Analiza ugotavlja, da je najpomembnejša značilnost stanovanja, ki so jo izrazili anketirani, mirna in zelena okolica (75 odstotkov). Kot pomembno jo je prepoznalo 94 odstotkov vprašanih. Druga najpomembnejša značilnost so bili dobri sosedski odnosi, tretje mesto pa je zasedla neodvisnost od drugih gospodinjstev. Osemdeset odstotkov anketirancev se je opredelilo, da je pomembno zagotovljeno parkirišče, in za kar 70 odstotkov je bilo pomembno imeti lasten vrt ali atrij. Medtem ko se bližina rekreacijskih poti ni uvrščala tako visoko, je bila še vedno pomembna za dobro polovico anketiranih (53 odstotkov).

\section{Metode dela}

Predstavljena primerjalna analiza enodružinskih naselij v Ljubljani, Mariboru in Novem mestu ${ }^{[1]}$ zajema nekatera najočitnejša skupinsko načrtovana naselja enodružinskih prostostoječih, vrstnih in atrijskih hiš ter stanovanjskih dvojčkov, zgrajenih v različnih obdobjih.

Analiza je bila izvedena po podatkih zemljiškega katastra in katastra stavb po stanju v maju 2007 po posameznih občinah, glede na zadnje ortofoto snemanje posameznih mest, upoštevajoč starejše topografske in ortofoto načrte ter terenski ogled $\mathrm{v}$ analizi zajetih naselij. Izbor teh obsega najpomembnejša naselja organizirane gradnje $\mathrm{v}$ izbranem časovnem preseku in predstavlja dovolj reprezentativen vzorec za analizo.

Za izvedbo primerjalne analize so bile prej opredeljene površine naselja glede na njihov značaj in funkcijo $\mathrm{v}$ naselju: konkretno naselje, parcela (predvrt, objekt, bivalni vrt), površina, namenjena motoriziranemu prometu: cesta, parkirišča, garaže, pešpoti, odprti prostor $\mathrm{z}$ opredeljeno funkcijo (otroška, športna igrišča, ostala rekreacijska območja, območja druženja ...), drugi odprti prostor (drevoredi, zelenice, obrobne proste površine ...). Za vsako naselje so bile narejene zbirne tabele iz zemljiškega katastra izvedenih podatkov. Glede na omenjene določene površine naselij so bili podatki grafično obdelani in predstavljeni glede na stavbni tip, naselje, mesto in obdobje nastanka.

Podobo naselja določajo njegova zgradba (število in raznolikost prostorskih elementov, poleg hiš še infrastruktura in odprti prostor) ter značilnosti navedenih sklopov in elementov. Pri primerjavi stanja naselij $\mathrm{v}$ treh slovenskih mestih so bila opredeljena podrobnejša merila za ugotavljanje stanja in kakovosti naselij $\mathrm{v}$ zadnjih štiridesetih letih:

- velikost naselja,

- število enot, pripadajočih opredeljenim stavbnim tipom,

- odnos med številom enot in površino naselja,

- povprečna velikost parcel (hiše in vrta) po stavbnih tipih,

- odnos med zazidano površino in vrtom,

- delež zemljišča predvrta, hiše in bivalnega vrta,

- delež zemljišč po opredeljenih površinah v naselju, in sicer po: stavbnih tipih (prostostoječa hiša, stanovanjski dvojček, vrstna hiša in atrijska hiša), naseljih, mestih in desetletnih obdobjih gradnje,

- površine infrastrukture: površina, namenjena motoriziranemu prometu (ceste, dovozne poti, parkirišča, garaže...), površina pešpoti in kolesarskih poti, "zbiralni otoki«, ostala območja infrastrukture, 
- odprti prostor z opredeljeno funkcijo (otroško igrišče, športno igrišče, druga rekreacijska območja, območja počivališč in druženja),
- drugi odprti prostori (zelene pregrade, drevoredi, zelenice, na robu naselja),

- posebni odprti prostori (deli širšega zelenega sistema).

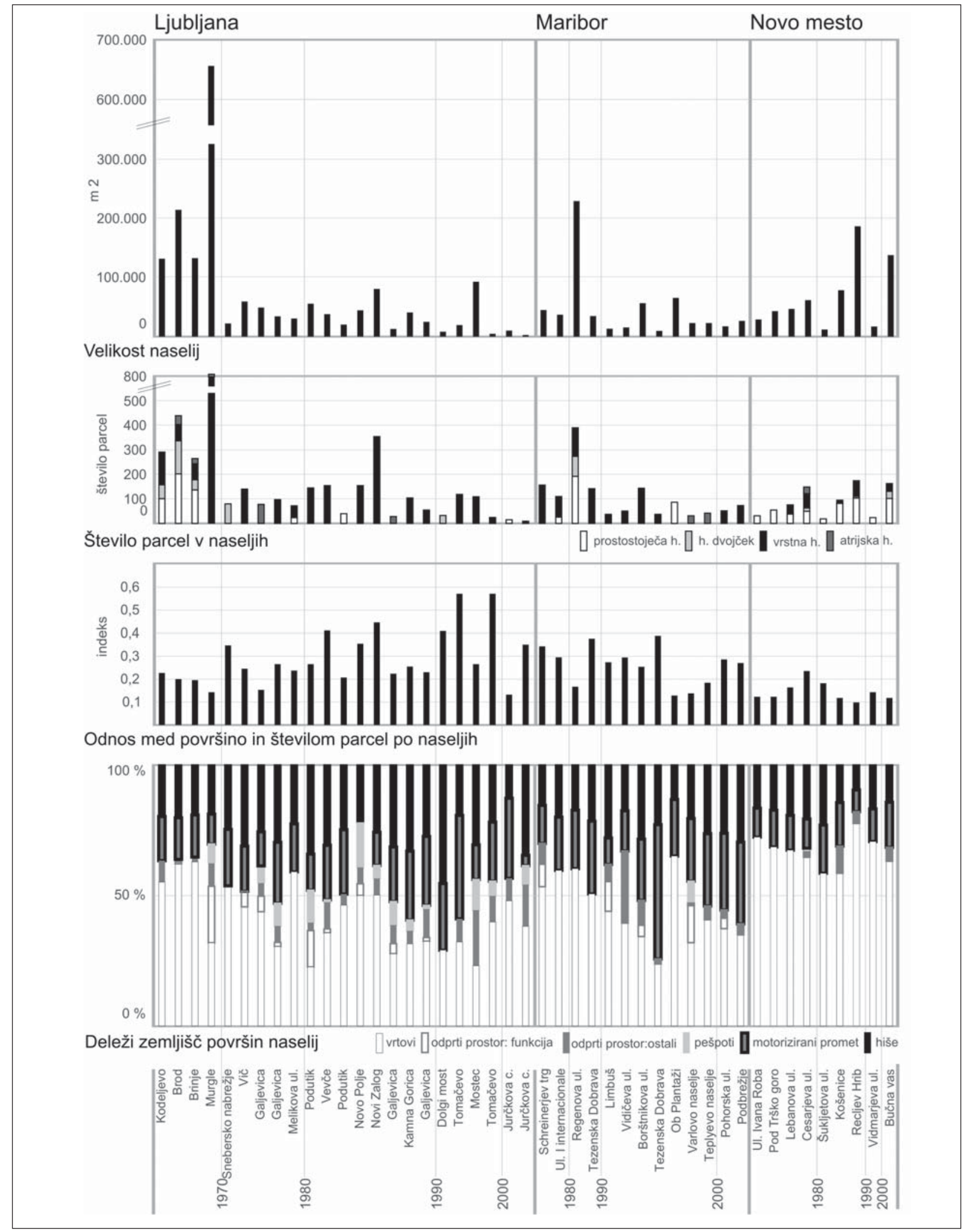

Slika 1: Graf velikosti naselij, števila parcel v naseljih, pozidanosti in skupnih deležev zemljišč površin naselij po mestih in obdobjih. 


\section{Rezultati in interpretacija primerjalne analize naselij enodružinskih hiš v Ljubljani, Mariboru in Novem mestu}

\subsection{Značilnosti naselij enodružinskih hiš, ki vplivajo na prostorsko podobo}

Primerjava s starejšimi naselji enodružinskih hiš v Ljubljani in Mariboru pokaže, da je delež odprtega prostora v novejših naseljih manjši, da so se odmiki med stavbami zmanjšali skoraj za polovico, skrčila pa sta se tudi ulični prostor in prostor vrtov. Parcele so se v povprečju zmanjšale za tretjino. Skupni deleži vrtov in naselju skupnih odprtih površin so manjši za polovico. Novo mesto v vseh upoštevanih merilih odstopa od povprečja. Z obdobji ostajajo parcele razmeroma enakih velikosti, prav tako površina naselja, pozidanost, faktor izrabe gradbene parcele in zastopanost odprtega prostora glede na rabo.

Ugotavlja se, da sta izkoristek in kakovost bivalnega vrta odvisna od zasnove naselja kot celote. Na kakovost individualne hiše vplivajo medsebojne povezave skupine hiš in drugih elementov naselja. Izkaže se, da je eden glavnih gradnikov kakovosti bivalnega okolja kakovostno zasnovan notranji in zunanji prostor. Načrtovanje obeh tako ne more biti neodvisno drug od drugega in mora potekati sočasno.

Očitno je zmanjševanje površin naselja. Po površini večja naselja so omogočala izoblikovanje zaključenih stanovanjskih skupin, medtem ko manjši načrtovani stanovanjski nizi med obstoječo poselitvijo teže dobivajo lastno prepoznavnost. Prav tako ni prehodov med posamičnimi stanovanjskimi nizi v okoliško poselitev. Skladno z zmanjševanjem površine naselja se zmanjšuje število zgrajenih enot. Posamezna zaključena naselja, zasnovana in izvedena kot organizirana gradnja pred letom 1970, so imela od 200 do 450 parcel v zaokroženem naselju (Murgle nad 800). Iz tega časa prevladujejo naselja z 80 do 150 parcelami. Novejša naselja pa imajo od 30 do 60 parcel. Očitno je tudi, da se v novejših naseljih gradi samo en tip hiš, mešanih in zato tudi pestrejših naselij pa skoraj ne več.

V naseljih v Ljubljani in Mariboru močno prevladuje gradnja vrstnih hiš. Sledi zastopanost atrijskih hiš in stanovanjskih dvojčkov. Najmanj je naselij prostostoječih hiš. V Novem mestu pa tip prostostoječe hiše močno prevladuje vseh zadnjih štirideset let in več.

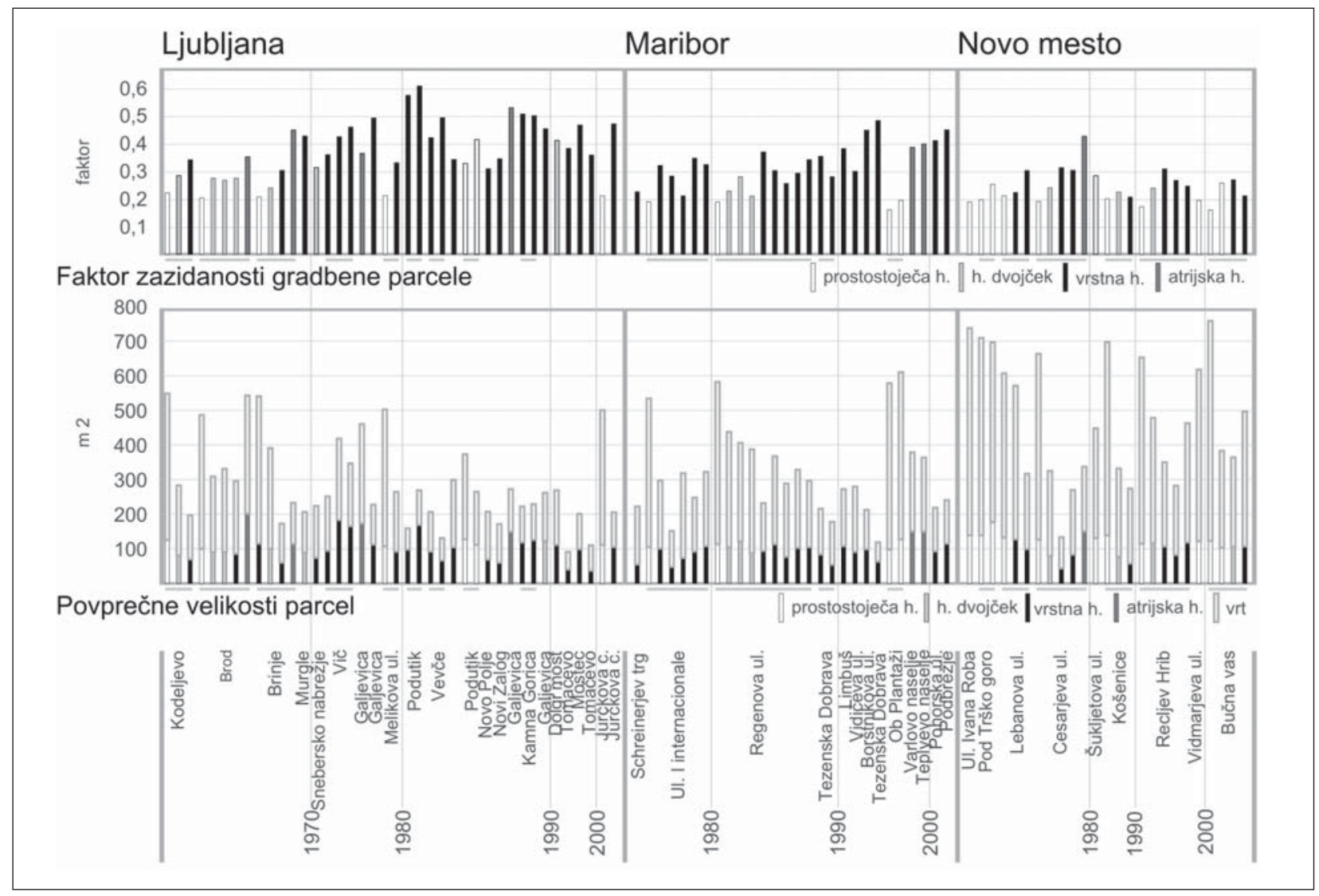

Slika 2: Graf faktorja zazidanosti gradbene parcele in povprečnih velikosti parcel po stavbnih tipih, mestih in obdobjih. 
Po obdobjih sta opazna večanje števila objektov in močno zgoščevanje poselitve na dani površini. Mesto Ljubljana ima večjo pozidanost naselij s povprečjem 0,282 oziroma več enot na površino naselja kakor Maribor s povprečjem 0,262 in Novo mesto $\mathrm{s}$ povprečjem 1,283 . To je razumljivo glede na višje cene zemljišč v prestolnici. Novo mesto ima v vseh obdobjih manjšo oziroma najmanjšo pozidanost naselij $\mathrm{v}$ primerjavi z Mariborom in Ljubljano in $\mathrm{s}$ tem kakovostnejši prostor in podobo.

Ne glede na obdobja in lego zavzema parcela enodružinske prostostoječe hiše največjo površino. Sledijo ji atrijska hiša in hiša dvojček in kot parcela z najmanj površine - vrstna hiša. Vrt je glede na razmerje hiša : vrt najmanjši pri atrijski hiši.

Največja nihanja povprečne velikosti parcele hiše in vrta $v$ zadnjih štiridesetih letih so opazna $v$ Ljubljani (hiša 70-170 $\mathrm{m}^{2}$, vrt $80-400 \mathrm{~m}^{2}$ ). Od 70 . let so opazni krčenje površine parcel in povečevanje velikosti hiše in s tem zmanjševanje vrta. V sredini 80 . let se površina vrta močno skrči (v Ljubljani s $150-400 \mathrm{~m}^{2}$ na $115-150 \mathrm{~m}^{2}$ ), čeprav se površina hiše znatno ne poveča. V Mariboru je površina zemljišča hiše razmeroma enaka ne glede na obdobje in tip zazidave. Površina vrta pa pri tem upada. Popolnoma drugače je v Novem mestu, kjer so parcele v splošnem veliko večje kakor v Ljubljani ali Mariboru ter ostajajo razmeroma enakih velikosti pri vseh tipih gradnje v vseh obdobjih. Po letu 1990 je v Novem mestu opazno celo povečevanje vrtne površine.

Skladno z ugotovitvami zmanjševanja velikosti parcel, povečevanja tlorisne površine hiše in zmanjševanja vrtne površine je faktor zazidanosti gradbene parcele najvišji v Ljubljani (med 0,205 in 0,616 ) in najnižji v Novem mestu (med 0,158 in 0,433). V Mariboru se giblje med 0,160 in 0,488 . Faktor zazidanosti gradbene parcele se v nekaterih naseljih poveča za polovico v primerjavi s starejšimi naselji.

V zadnjih letih se gradi čedalje manj naselij, v katerih bi se promet ustavil na obodu in bi bila prehodnost med posameznimi stanovanjskimi skupinami urejena s pešpotmi. Tako organizacijo ima nekaj starejših naselij, $\mathrm{v}$ katerih dostopne in povezovalne ceste s skupnimi parkirišči in garažami (navadno na koncu ali začetku niza, redkeje v sredini nizov) ločujejo stanovanjske skupine med seboj. Večina novejših naselij pa je organiziranih tako, da je predviden dostop $\mathrm{z}$ avtom do vsakega vhoda in s parkiranjem $\mathrm{v}$ garaži $\mathrm{v}$ hiši, zato imajo veliko več površin namenjenih motoriziranemu prometu. V njih obsegajo

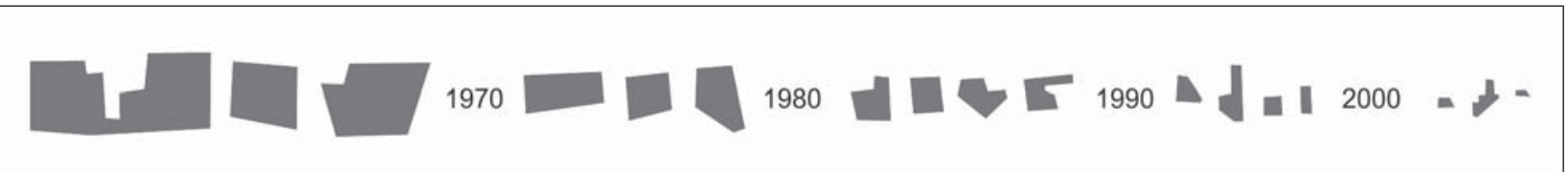

Slika 3: Shema velikosti nekaterih analiziranih naselij v Ljubljani in Mariboru po obdobjih.

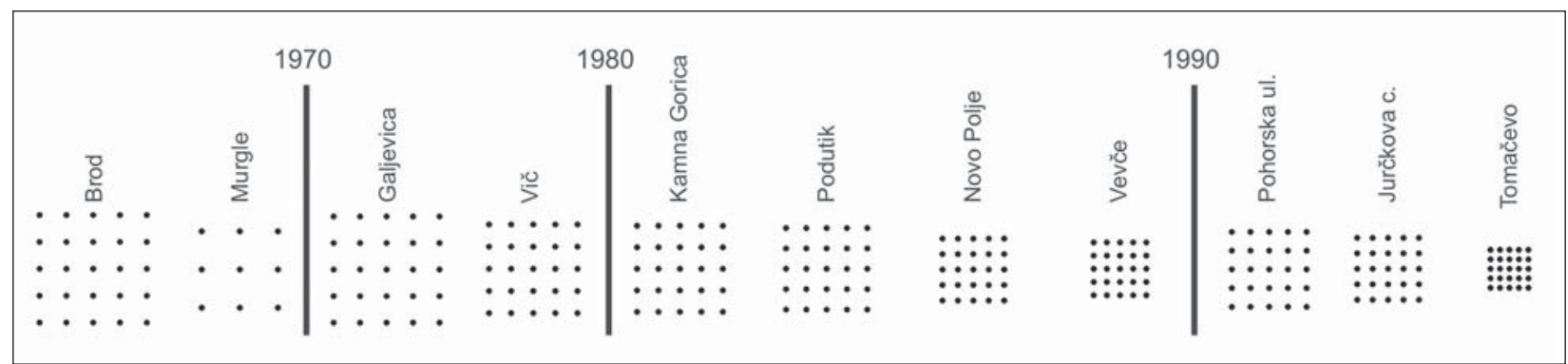

Slika 4: Shema zgoščevanja poselitve - povečevanje števila objektov na dani površini.

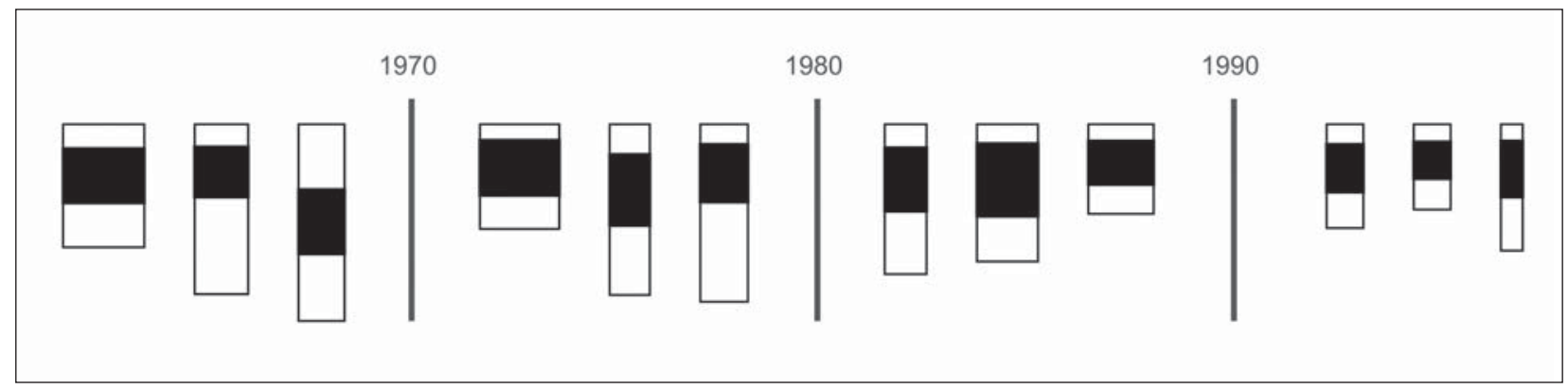

Slika 5: Shema zmanjševanja parcel vrstne hiše v Ljubljani in Mariboru po obdobjih. 
največ utrjenih površin same ceste, manj pešpoti in druge tlakovane površine.

Poti $\mathrm{v}$ novejših naseljih so ne glede na to, ali so namenjene motornemu ali pešprometu, praviloma širše (5-10 m ceste, 3-5 m pešpoti) kakor v starejših zasnovah (4-8 $\mathrm{m}$ ceste, 1-2,5 $\mathrm{m}$ pešpoti), vendar ostaja cestni koridor v starejših naseljih zračnejši, dopolnjen $z$ drevorednimi potezami in skupnim javnim zelenim prostorom.

\subsection{Oblikovanje ulice in odprtega prostora v naseljih enodružinskih hiš}

Pomen odprtega prostora v naseljih enodružinskih hiš je predvsem v zagotavljanju površin hišam pripadajočih vrtov, tako da je zagotovljena individualnost $\mathrm{v}$ razvoju in delovanju posameznih bivalnih enot. Glede na organizacijo naselja je od bivalnih vrtov in predvrtov odvisna gostota zazidave oziroma odmik med hišami. Manjšanje površin vrtov in/ali višanje objektov zgoščuje pozidavo in narobe. Druge odprte površine ceste, parkirišča, poti, zelenice, drevoredi in dodatne skupne zelene površine za rekreacijo, igro in druženje lahko popravijo odmike, dajejo celostni podobi naselja svojevrsten značaj in v naselju glede na intenzivnost svojega zastopanja ustvarjajo boljše bivalne razmere. Večja naselja imajo znotraj in na obrobju več javnih in poljavnih skupnih površin. Zastopanost skupnih odprtih površin z opredeljeno funkcijo (otroško, športno igrišče, druga rekreacijska območja, območja druženja ...) je večja v starejših naseljih (10-20 odstotkov), medtem ko so v novejših zelene površine večinoma samo zeleni pasovi med naseljem in zanj izključujočimi rabami. Opuščajo se drevoredi in drugi ulični prostor. Predvsem pa je v novejših naseljih zastopanost skupnih odprtih površin odvisna od standarda stanovanjskega naselja. Iz naselij $\mathrm{z}$ minimalnimi standardi so izvzete vse skupne dodatne odprte površine (drevoredi, zelenice, igrišča ...). Zlasti v nadstandardnih naseljih pa je zelenih prvin odprtega prostora več.

Delež skupnih površin vrtov je v Novem mestu največji (od 60 do 70 odstotkov celotne površine naselja), manjša sta delež skupne površine zazidanih zemljišč (od 10 do 25 odstotkov celotne površine naselja) in delež skupnih površin, namenjenih motoriziranemu prometu (od 10 do 15 odstotkov celotne površine naselja). Delež skupnih površin vrtov v Ljubljani je najmanjši (od 25 do 4060 odstotkov celotne površine naselja). Podobno je v Mariboru, vendar prevladujejo naselja s 40 odstotki ali več skupne površine vrtov.

Poleg zasedenosti parcele vplivajo na podobo ulice gabariti objektov, njihova širina in predvsem višina. Medtem ko v starejših naseljih prevladujejo pritlični objekti, so novejše rešitve vedno enonadstropne hiše, zato se je razmik med objekti zmanjšal za skoraj polovico skupne dolžine poti in vrtov (Tomačevo $\mathrm{d}=2,8 \mathrm{~h}$, Murgle $\mathrm{d}=5 \mathrm{~h}$, Podutik d = 3,2 h, Kamna Gorica $d=4,2 \mathrm{~h})^{[2]}$. Stanje je nekoliko drugačno $\mathrm{v}$
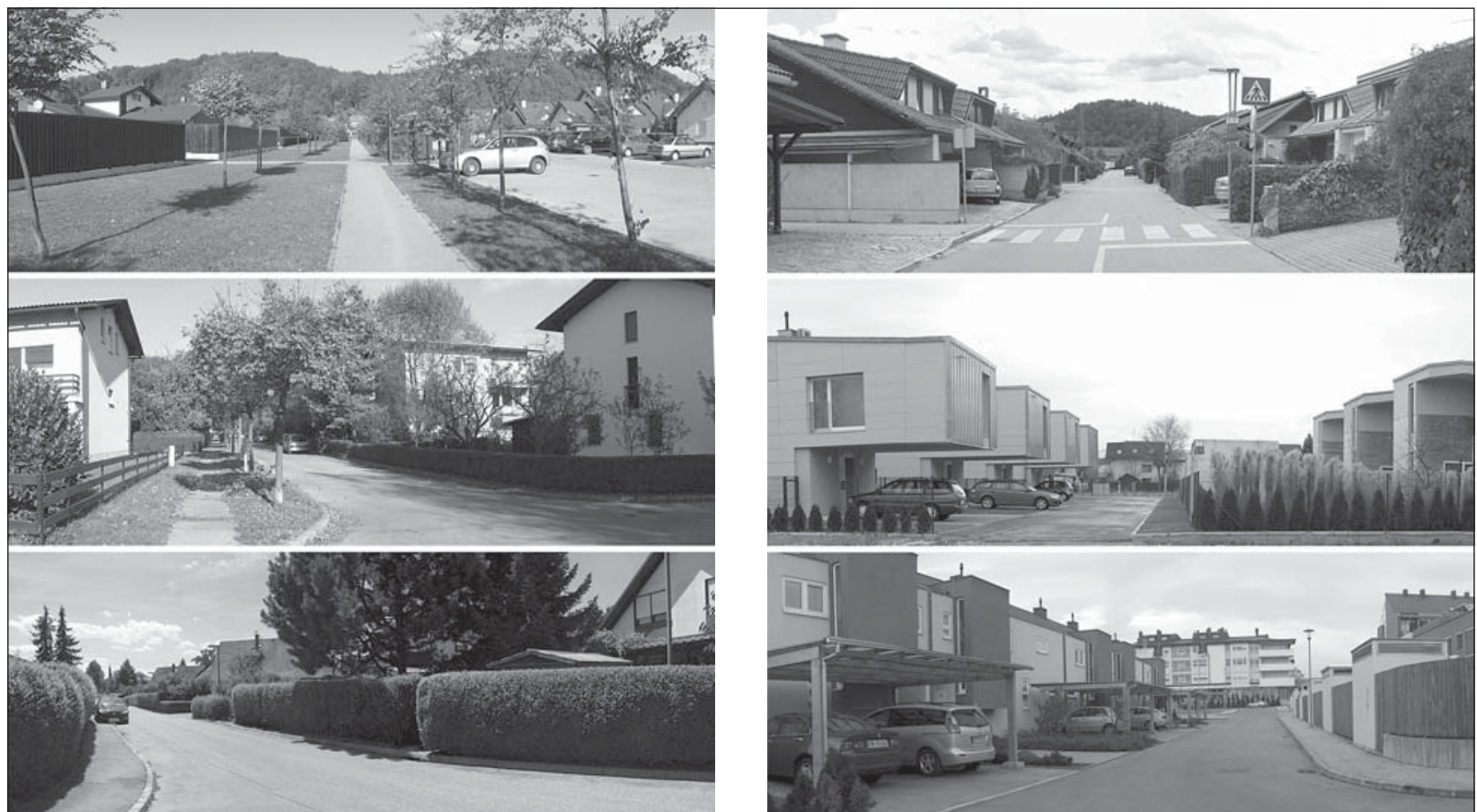

Slika 6: Ulični prostor cest, namenjenih motoriziranemu prometu. Primeri na levi so iz starejših naselij, ulica je širša, ozelenjena. Primeri na desni so iz najnovejših naselij, ulica je ožja, bolj pozidana, dreves skorajda ni več. (Foto: Nika Cigoj) 
naseljih z višjimi standardi, pri katerih so dimenzije vrtov podobne tistim v naseljih starejšega nastanka, odmiki med objekti pa podobni nižjim standardom zaradi $\mathrm{P}+1$ stanovanjskih objektov (Jurčkova cesta $\mathrm{d}=0,89 \mathrm{~h}$, Pohorska ulica $\mathrm{d}=2,7 \mathrm{~h}$ ).

Poleg dimenzij hiši pripadajočega odprtega prostora vpliva na odmike med objekti tudi konkretna ureditev uličnega prostora $\mathrm{v}$ naseljih. V novejših naseljih se skladno s povečevanjem gostote objektov in ožanja parcel močno oži tudi ulični prostor. Kar zadeva bivanjsko kakovost, so ustreznejša tista naselja, v ka- terih je razmik med stanovanjskimi stavbami širši oziroma je v ulični prostor vnesenih več dodatnih odprtih površin, kakršne so zelenice in drevoredi, ki poleg ustvarjanja medprostora med objekti zagotavljajo boljšo mikroklimo v naselju. Zelene prvine v novejših ulicah so redke, drevoredi se opuščajo, prevladuje minimalni razpoložljivi prostor za cesto in pločnik ob njej.

Pri povezovalnih poteh oziroma poteh $\mathrm{v}$ manjših naseljih je podoba ulice odvisna predvsem od ureditve (koliko zelenih površin bo vnesenih $\mathrm{v}$ profil

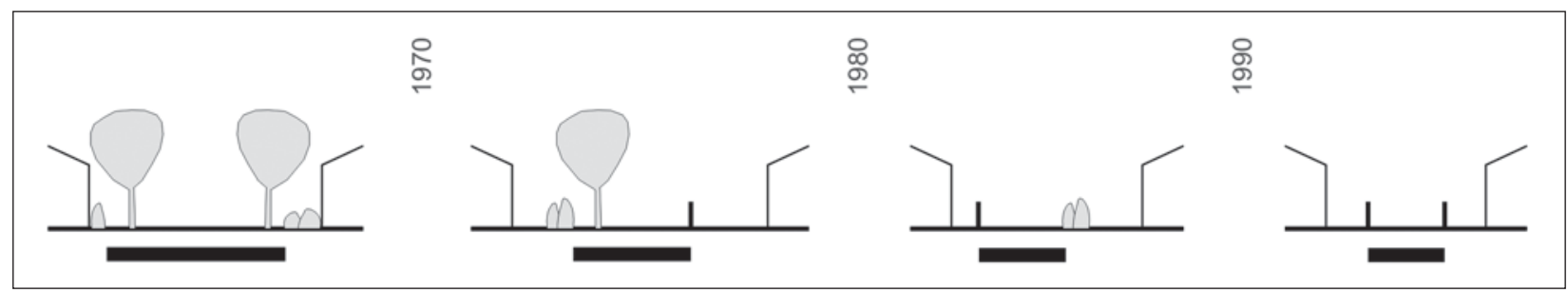

Slika 7: Sheme uličnega prostora ceste v Ljubljani in Mariboru po obdobjih.
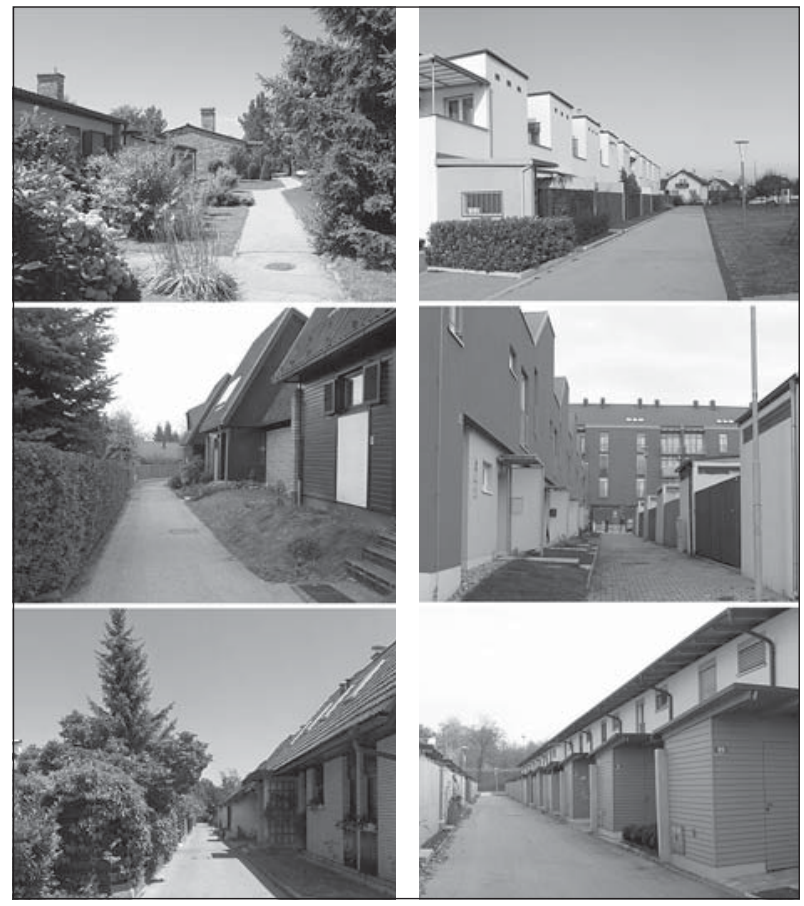

Slika 8: Ulični prostor pešpoti. V starejših naseljih so pešpoti del celostno zasnovanega zelenega prostora (primeri na levi). Novejše rešitve zmanjšajo poti na kar najmanjše prehode. (Foto: Nika Cigoj) ulice) in širine predvrtov. V zadnjih desetletjih sta se pešpot in s tem običajno predvrt zožila skoraj za polovico. Pri novejših naseljih z višjim standardom so predvrt in pešpoti sicer nekoliko širši, vendar se predvrt prostorsko dojema kot del poti ali ceste. Tako postane meja med javnim in zasebnim prostorom zabrisana, kar je lahko pri majhnih oz. ozkih ulicah dodatno moteče.

$\mathrm{V}$ večini novejših naselij ni prepoznati celostnega krajinskega oblikovanja odprtih površin. Oblikovanje je omejeno na zagotavljanje minimalnih potrebnih elementov za delovanje naselja (tlaki, klopi). Redka naselja imajo urejene otoke za zbiranje smeti in podobno. Površine, ki jih naselje izrabi in tudi vsak dan uporablja, so večje in umeščene bolj središčno glede na celotno naselje in so tako enako dostopne vsem prebivalcem. Razdrobljenost površin in njihova velikost vplivata na stopnjo njihove izrabe. Manjše površine so ne glede na lego v naselju manj izrabljene za dodatne dejavnosti. Bolj so pod vplivom interakcij z okoliškimi objekti in nasprotno. Deli manjših odprtih površin, zlasti tistih, ki nastanejo ob izpustih hiš med nizi, se ponavadi uporabljajo kot dodatna parkirišča ali za dozidavo garaž

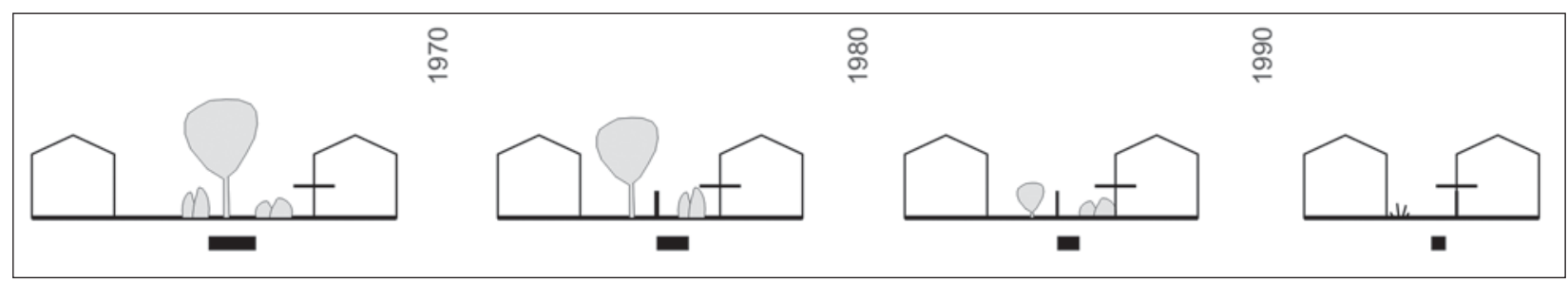

Slika 9: Sheme uličnega prostora pešpoti v Ljubljani in Mariboru po obdobjih. 

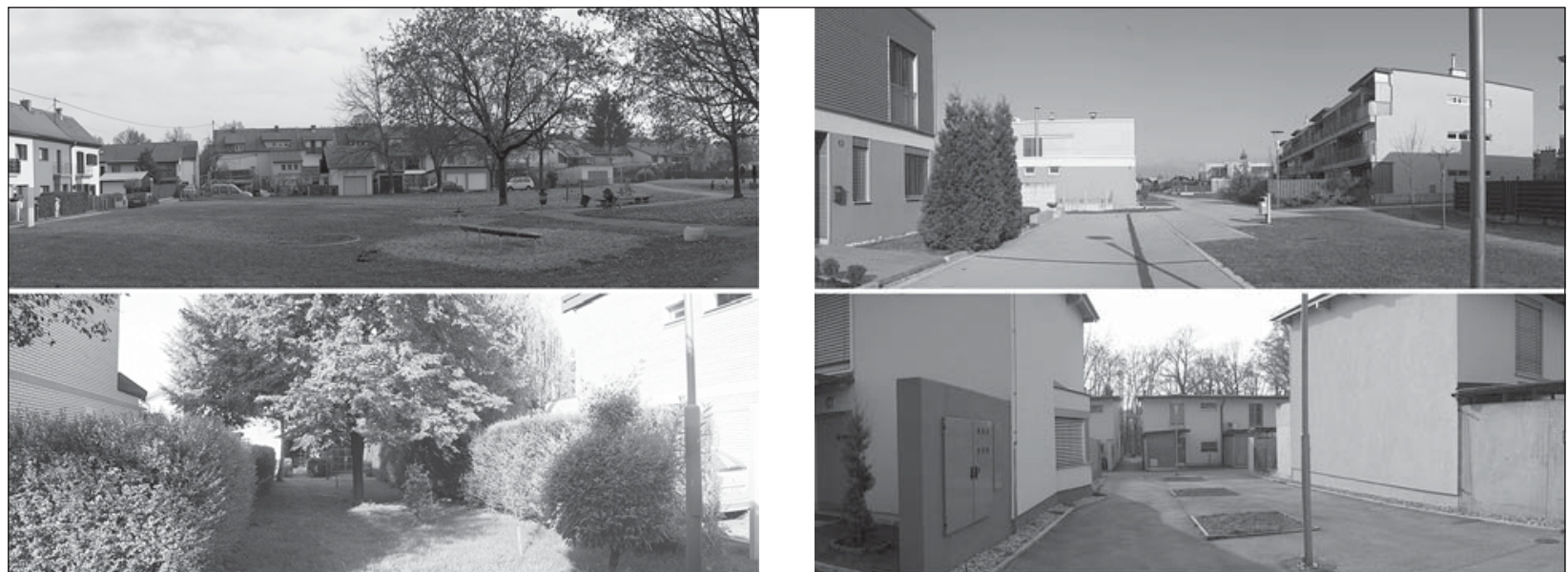

Slika 10: Skupni odprti prostor obravnavanih naselij enodružinskih hiš. V starejših naseljih so skupni odprti prostori zasajeni, namenjeni so druženju, igri in rekreaciji (primera na levi). V novejših naseljih se te površine izgubljajo (primera na desni). (Foto: Nika Cigoj)
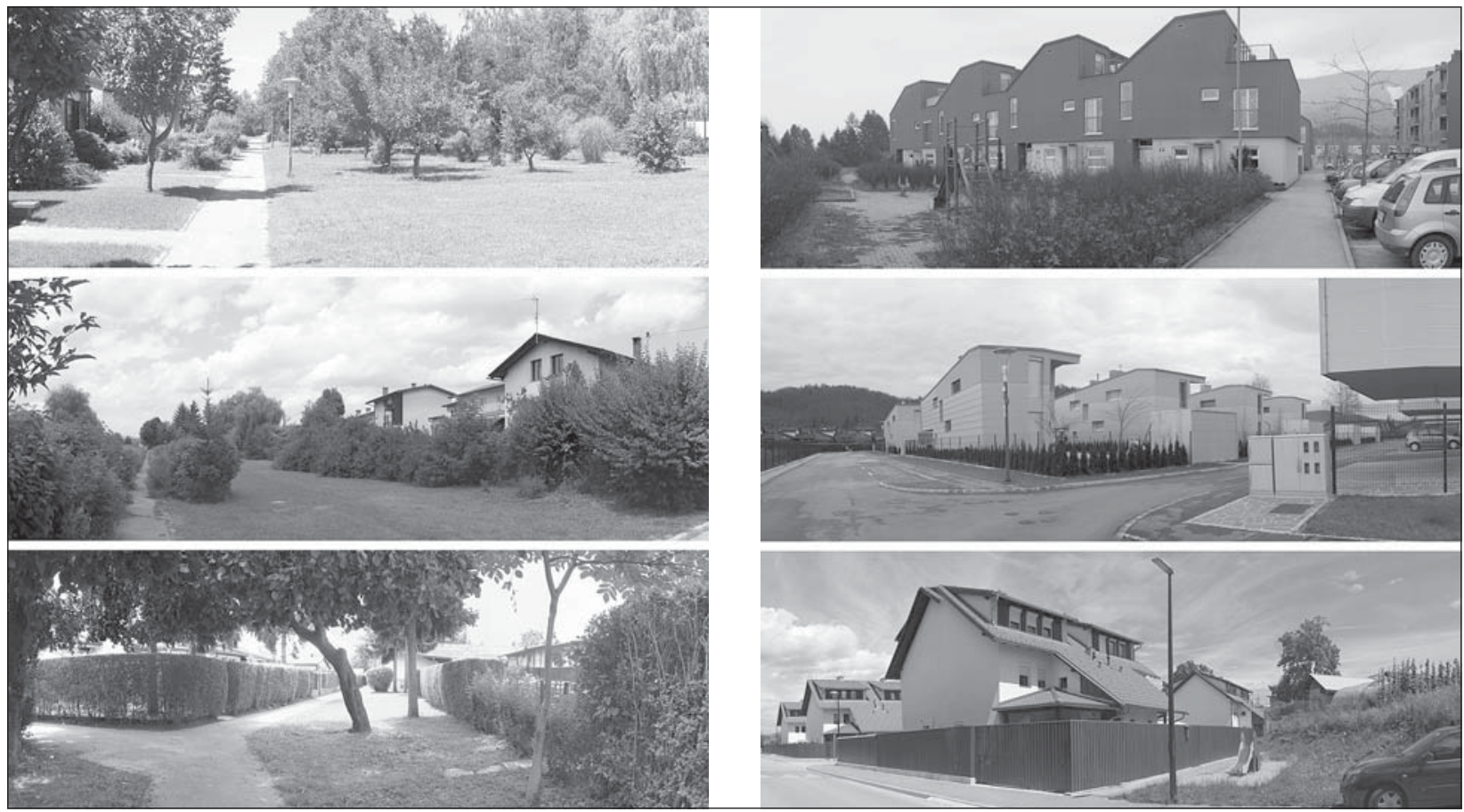

Slika 11: Obrobne odprte površine v obravnavanih naseljih enodružinskih hiš, starejša naselja - slike na levi, novejša naselja - slike na desni. (Foto: Nika Cigoj)

in prizidkov. Odprte površine na obrobju naselij so si prebivalci večinoma prisvojili in jih uporabljajo kot podaljške svojih vrtov.

\section{Sklep}

Večja naselja s kakovostno zasnovanimi odprtimi površinami, skupnim zelenim prostorom ali vsaj široko in strukturirano ulico in predvrtovi se skorajda ne gradijo več. Nastajajo manjša naselja na prostorsko omejenih parcelah, s katerimi poskušajo investitorji $\mathrm{v}$ danih razmerah na trgu nepremičnin iztržiti čim več. Odprti prostor se ne oblikuje več. Prostor urejajo količniki, razmerja, pisne opredelitve, premalo je vnaprej pretehtanih zazidalnih načrtov, ki bi poleg osnovnih pogojev obogatila naselja s kakovostnim zelenim prostorom, kar bi izboljšalo vizualno podobo. Velikost območja, namenjenega novogradnji, bistveno vpliva na urbanistično zasnovo naselja. »V mnogih primerih se $\mathrm{v}$ manjših območjih obračajo tudi skromna finančna sredstva investitorjev, kar lahko skupaj s pomanjkanjem prostora pomeni dodatno oviro za ureditev kakovostne stanovanjske krajine" (Simoneti in Vertelj Nared, 2006: 28). To potrjujejo tudi ugotovitve primerjalne analize naselij. 
Vzporednice slabšanju bivanjske kakovosti gre iskati tudi v premajhnem udejstvovanju strokovne in laične javnosti pri vprašanju kakovosti stanovanjske kulture, ukvarjanja z naseljem kot celoto, z njegovimi celovitimi razmerji med hišo in odprtim prostorom. Večina novejših raziskav se osredotoča zgolj na strukturne značilnosti ponudbe, pri čemer jih zanimajo ekonomske razsežnosti procesov, tipološke in morda lokacijske preference kupcev, nikakor pa ne prostorske, oblikovalske in podobno (Stanovanjski sklad Republike Slovenije, 2004).

Slovenski trg nepremičnin je premajhen, pomanjkanje stanovanj zlasti v večjih mestih pa preveliko, da bi trg uravnaval kakovost ponudbe novogradenj. Nekdaj veljavni urbanistični normativi so v veliko pogledih zastareli in se jih sproti nadomešča z novejšimi, popravljenimi zahtevami po količini smetnjakov, številu parkirnih prostorov, tehničnih elementih cest ipd. Žal pa nekdaj uveljavljenih normativov, ki so podrobneje določali količino in kakovost odprtega prostora, ne posodabljamo in ne uporabljamo več, zato ne preseneča, da ponujajo starejša naselja precej kakovostnejšo podobo od novejših utesnjenih ulic z visokimi enodružinskimi hišami, zaparkiranimi pločniki in neurejenimi ostanki odprtega prostora. Po skoraj dvajsetih letih zanašanja na novo tržno logiko je že jasno, da tržni mehanizmi kakovostne gradnje naselij enodružinskih hiš v Sloveniji ne delujejo oz. ne zagotavljajo boljše ponudbe, zato ostaja za prihodnost urbanističnega načrtovanja eno ključnih vprašanj razmerje med izrazito tržno usmerjeno gradnjo s svojimi tranzicijskimi prostorskimi značilnostmi in med organizirano ter normativno regulirano gradnjo, ki bi ohranjala vsaj nekoč že osvojene kakovostne rešitve.

\section{Opombe}

[1] Analiza naselij enodružinskih hiš zajema 43 naselij v Ljubljani, Mariboru in Novem mestu. Izvedena je bila v diplomskem delu z naslovom Gradnja enodružinskih hiš v Sloveniji po I. 1990 in oblikovanje zelenih površin (N. Cigoj, mentor: D. Gazvoda) na Oddelku za krajinsko arhitekturo Biotehnične fakultete Univerze v Ljubljani. Analiza je bila izvedena po podatkih zemljiškega in stavbnega katastra po stanju $\mathrm{v}$ maju 2007

[2] $\mathrm{d}$ = povprečna dolžina razmika med objektoma, $\mathrm{h}$ = povprečna višina objekta $v$ analiziranih naseljih.

\section{Viri in literatura}

Bevk, M. (1996) Novi trendi v individualni gradnji. Enodružinska hiša $\checkmark$ Sloveniji 45-95. List, Glasilo Društva arhitektov Ljubljane, 17(posebna številka), str. 80-81.

Bojovič, B. (1984) Pregled nad družbeno politiko stanovanjske gradnje $\checkmark$ Jugoslaviji. Aktualni problemi razvoja stanovanjske gradnje $\vee$ Sloveniji. Arhitektov bilten, Glasilo Društva arhitektov Ljubljane, 68/69 (posebna številka), str. 5-7.

Ivanšek, F. (1998) Enodružinska hiša: od prostostoječe hiše k nizki zgoščeni zazidavi. Ljubljana, Ambient.

Koselj, N. (2005) Enodružinska hiša v času slovenskega povojnega modernizma. Hiše (izbor sodobne slovenske stanovanjske arhitekture), 26(5), str. 36-41.

Krušec, T., in Žaucer, T. (1998) Leta jasne vizije. Enodružinska hiša v Sloveniji 45-95. Glasilo Društva arhitektov Ljubljane, 17(posebna številka), str. 61.

Šašek-Divjak, M., Sendi, R., Jakoš, A., in Cirman, A. (2002) Kakovost stanovanjske oskrbe in bivalnega okolja: zaključno poročilo o rezultatih opravljenega raziskovalnega dela na projektu v okviru ciljnih raziskovalnih programov. Ljubljana, Urbanistični inštitut Republike Slovenije.

Simoneti M., in Vertelj Nared, P. (2006) Analiza večstanovanjske gradnje v Ljubljani, v: Gazvoda, D. in Simoneti, M. (ur.) Stanovanjske krajine: trendi, perspektive, str. 25-33. Ljubljana, Biotehniška fakulteta, Oddelek za krajinsko arhitekturo, Zavod za prostorsko kulturo TrajekT.

Mandič, S., Hlebec, V., Cirman, A., Dimitrovska Andrews, K., Filipovič, M., Kos, D., Sendi, R., in Gnidovec, M. (2006) Stanovanjska anketa. Ljubljana, Fakulteta za družbene vede, Center za proučevanje družbene blaginje. Stanovanjski sklad Republike Slovenije (2004) Raziskava o varčevanju v nacionalni stanovanjski varčevalni shemi. Ljubljana.
Nika Cigoj, univ. dipl. inž. kraj. arh.

Prostorsko načrtovanje Aleš Mlakar s.p.

E-pošta: ncigoj@gmail.com

Dr. Davorin Gazvoda, univ. dipl. inž. kraj. arh., izredni profesor

Biotehniška fakulteta, Oddelek za krajinsko arhitekturo

E-pošta: davor.gazvoda@bf.uni-lj.si 